原子層成長装置用ダイヤフラム・バルブ*

日本スウェージロック FST 株式会社*1

\title{
Diaphragm Valve for Atomic Layer Deposition Process Tools
}

Nippon Swagelok FST, Inc.

1-1-1 Naruohama, Nishinomiya, Hyogo 663-8142, Japan

(Received August 30, 2010, Accepted November 22, 2010)

\section{1. はじめに}

半導体素子構造の微細化が進み, 従来の化学気相成長 (CVD) やスパッタリングと言った薄膜成長技術に加えて関 心を寄せられているのが, Atomic Layer Deposition (ALD) と呼ばれるオングストローム・レベルでの成膜を行うための 半導体製造プロセス技術である. 本稿は, この ALD プロセ スに対応できるバルブの開発・製造に対して行ったバルブ . メーカーとしての取り組みを紹介する.

\section{ALD プロセスに於けるバルブに対するニー ズと開発課題}

ALD プロセスは, 反応チャンバー内で複数の成膜材料化 合物（前駆体）を交互に供給し, 繰り返し反応させる. その ため ALD 装置に用いられるバルブには, 従来の CVD 装置 のようなガス流量コントローラーやガス圧力調整器などのコ ンポーネンツで構成されたシステムとは異なり, ALD プロ セスならではの以下のニーズが提示されてきた.

(1) 低い蒸気圧の前躯体を安定供給するための耐熱性

(2) 前駆体とパージ・ガスそれぞれの適正量を短時間で確 実にコントロールするための流量安定性

(3) 前駆体の混合を確実に避けつつ極短時間でプロセスを 繰り返すための高速応答性と高い締切り性能

(4) 一層当たり数十から数百回のバルブ開閉サイクルを行 いウェハー上に希望通りの薄膜を成長させながら製造プ ロセスを継続して行うための耐久性

これらのニーズを受け, 我々は以下の ALD プロセス用バル ブの開発課題を設定した.

- 高温仕様 $\left(\sim 200^{\circ} \mathrm{C}\right)$

・安定して再現性のある流量

・高速のバルブ開閉動作（う数ミリ秒）

・長寿命（>1,000万回）

しかし，これらを元に ALD プロセス用バルブを開発するこ とは，「バルブ屋」にとって問題の連続であった．以下にそ れぞれの課題に対する取り組みとその成果の概要を示す.

\footnotetext{
$*$ 平成 22 年 6 月 2 日 日本真空協会 2010 年 6 月研究例会で講演
}

*1 于663-8142 兵庫県西宮市鳴尾浜 1 丁目 1 の 1

\section{3. 半導体製造プロセス用バルブの基本構造}

バルブでは, 一次側（入口）から導入されたシステム流体 が二次側（出口）から出てくるが，その間のバルブ・シート で流体の ON-OFF を行なっている (図1参照).

図 1 はダイヤフラム・バルブの中で最も一般的なスプリ ングレス・ダイヤフラム・バルブャ1 (以下, 単に「ダイヤフ ラム・バルブ」と呼ぶ)である. 従来, バルブでは対外部シー ルをパッキン等で行なっているためパッキンの磨耗による リークのリスクが伴っていたが，金属ダイヤフラムを用いる ことで，この磨耗によるリスクを大いに低減している。

ダイヤフラム・バルブでは, ドーム型をしているダイヤフ ラムの中央部がピストンのストロークによって押され 0.5 $\mathrm{mm}$ 前後のたわみを起こしてダイヤフラムがバルブ・シート に密着することでシールを形成している（図1(c)参照)。こ のドーム型ダイヤフラムとバルブ • シート間の僅かな隙間に よって半導体製造に必要なガス量を供給しているのである.

バルブを作動させるには手動, 自動の 2 つ方式がある が，半導体製造装置に於いては自動式，特に図 1 に示した ような空気作動式が一般的である. 図 1 中の 2 種類のダィ ヤフラム・バルブは, 空気導入口から空気等のガスを導入す ることでピストンを押し上げてバルブ・シートを開状態にす る「通常閉型」あるいは「ノーマル (ノーマリー)・クロー ズ型」と呼ばれ, 停電時等の異常時に作動用ガス供給源が止 まれば自動的にバルブが閉をることから広く用いられている.

\section{4. 課題への取り組み}

\section{1 高温仕様}

ALD プロセスではバルブに高速作動が求められるが, 我 々は電磁作動式より作動信頼性が高く, 数十年に渡り採用し てきた空気作動式を ALD プロセス用バルブにも採用した. しかし, このことにより, 高温の ALD 前躯体ガスの導入に よるバルブ・アクチュエーターの作動不良（不十分なステム の上下動やステムの水平方向に対するブレ), バルブ内温度

†1 初期に半導体用として開発されたダイヤフラム・バルブは, 平 坦なダイヤフラムを用いていたため, ダイヤフラムを待ち上げ る, 即ちバルブを開けるためのスプリングを流体と接触するバ ルブ・ボディ内部に設けていた.「スプリングレス」とは, こ れとは異なりバルブ・ボディ内部にスプリングを持たない構造 であることを示している. 


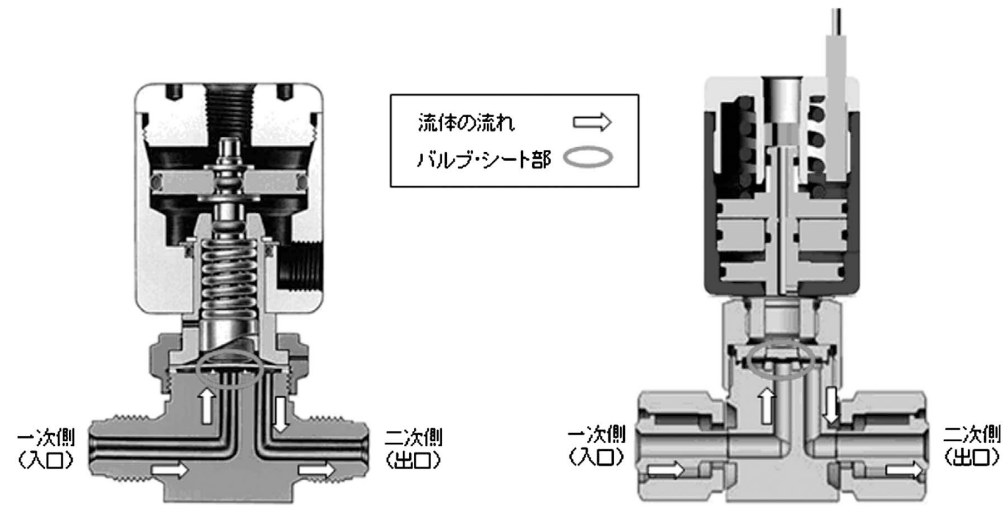

a)スプリングレス・ダイヤフラム・バルブ

b) ALDシステム用ダイヤフラム・バルブ

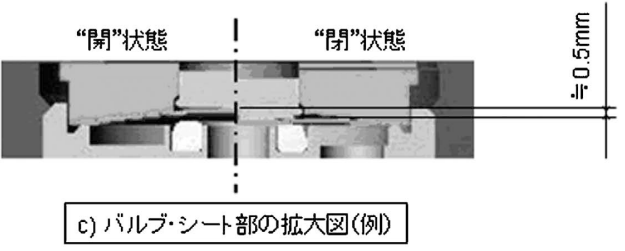

図1 バルブ構造の比較

の均一性, シート膨張による流量低下等の問題が浮かび上が ってきた.

高温下でのアクチュエーターの作動不良の原因は, 流体の 熱やバルブ保温のための熱が，バルブ・ボディを介してアク チュエーターに伝わり，その中のピストン・シリンダーとピ ストン間の摩擦を低減するために使用している潤滑剤の油分 を蒸発させてしまうことにある. 我々はアクチュエーターの 直下に断熱カップリングを加えることで，この熱の伝播を抑 え, アクチュエーターの作動不良を解消した (図 2 参照). 左側の断熱カップリング付きのアクチュエーター部は $50^{\circ} \mathrm{C}$ 前後の低温であるが, 右側の断熱カップリング無しのアクチ ュエーター部は $100^{\circ} \mathrm{C}$ 超の温度になっている.

次のシート膨張による流量の低下であるが，これは「安定 して再現性のある流量」とも関連しているので, 次章で併せ て触れることとしたい。

\section{2 安定して再現性のある流量}

前述したように, $0.5 \mathrm{~mm}$ 前後のダイヤフラムのたわみに よりバルブの開閉を行なっており， $\mathrm{Cv}$ 值 ${ }^{\dagger 2}$ は $0.3 \pm 10 \%$ であ る.この「たわみ」はピストンのストロークによって生じる ので, ピストン, アクチュエーター・ボタン, ピストン・シ リンダー等のバルブ構成部品の製造公差をこれまで以上に厳 密に管理すると同時に，敢えて強制的にピストンを押し下げ ることで生じるスプリングの反力を利用して, 全開時の流量 を実用的な範囲内で僅かに抑えることと引き換えに, 安定し たストローク，つまり流量が得られるようにした．このスプ リングによる「ピストンの押し下げ」は，図 2 に示した「フ

†2 流量係数の略称. 流量係数とはバルブ前後の差圧を $1 \mathrm{psi}(6.9$ kpa）に保った状態で, 華氏60度（摂氏15度）の水が 1 分間当 たりに流れる量を米ガロン（米 1 ガロン $3,800 \mathrm{~cm}^{3}$ ) で表し た数值（無次元）例えば, 上記差圧および温度条件で水が 1 米 ガロン流れた場合の流量係数 $(\mathrm{Cv}$ 值) は 1 である.

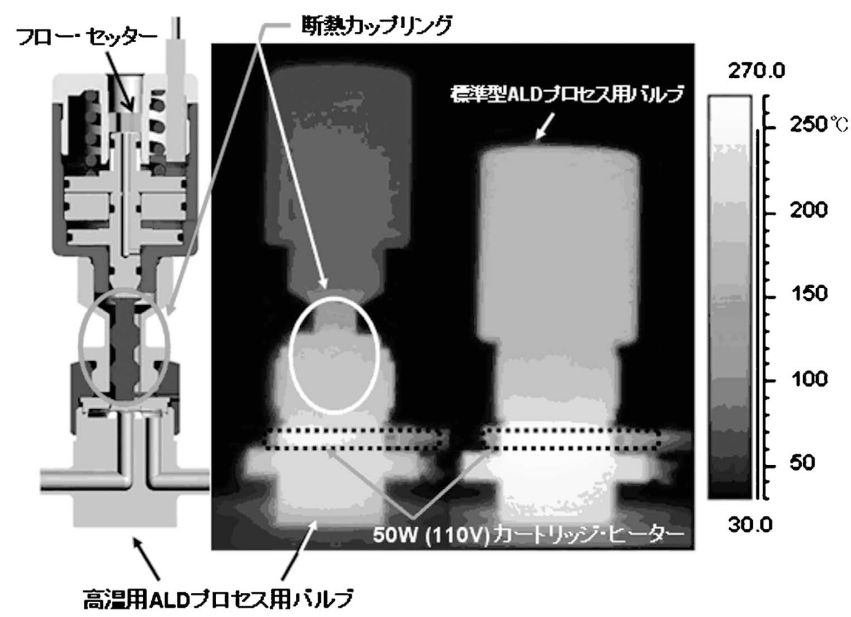

図 2 バルブの温度分布比較

左端の図は高温対応の ALD プロセス用ダイヤフラム・バ ルブのカット図

ロー・セッター」を用いて出荷前に $\mathrm{Cv}$ 值が $0.27 \pm 3 \%$ にな るように全数に対して行っており, バルブ開時の流量の安定 だけでなく, バルブ間の流量のバラつき制御の面からも性能 向上に大いに寄与した.

高温に於いては，材料の熱膨張による影響も考慮する必要 がある. シート素材として, 耐熱性だけでなく半導体グレー ドの純度を持ち，耐ストレスクラックに優れたDuPont ${ }^{\mathrm{TM}}$ 社製 PFA-450HP®採用し，これをべースにして有限要素 法解析を利用したシール形成時（バルブ閉時）の荷重による シート部の変形や温度変化に伴う变形 (膨張) のコンピュー ター・シミュレーションを繰り返し行い, 負荷時, 加熱時の バルブ・シートの挙動を把握した上でバルブ・シート形状の 設計を行なった．その結果, $200^{\circ} \mathrm{C}$ 於ける $\mathrm{Cv}$ 值は $20^{\circ} \mathrm{C} に$ おけるそれに対し約 $20 \%$ 程度の低下に抑制できていること 


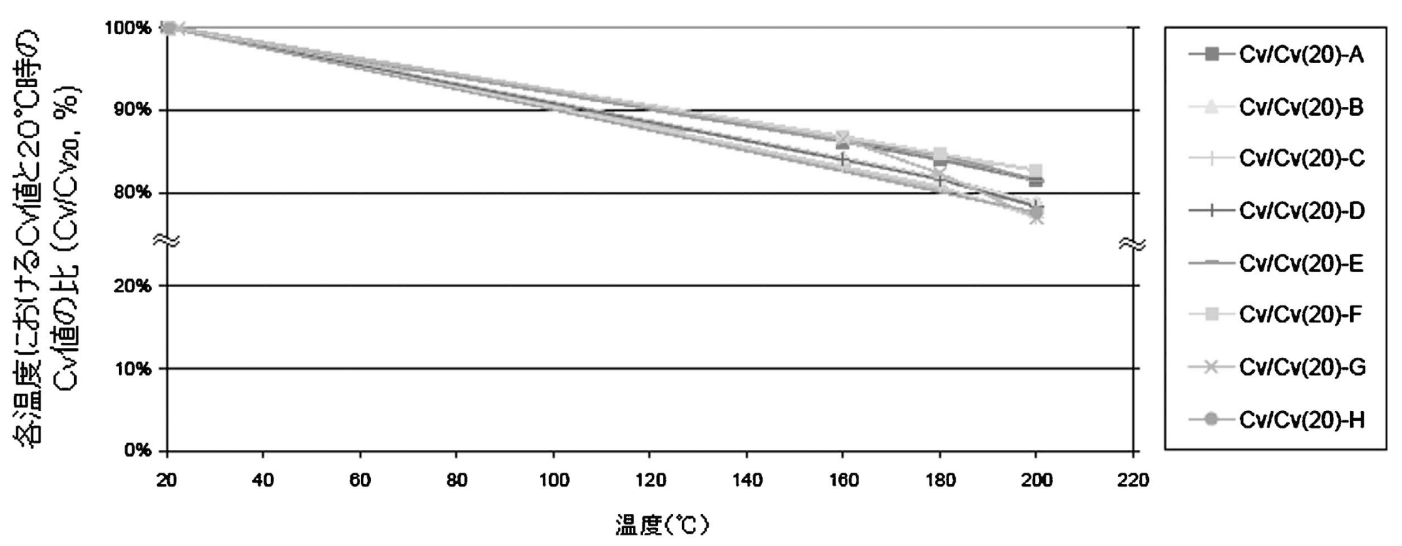

図 $320^{\circ} \mathrm{C}$ 時と各温度に抢ける $\mathrm{Cv}$ 值比の個体差

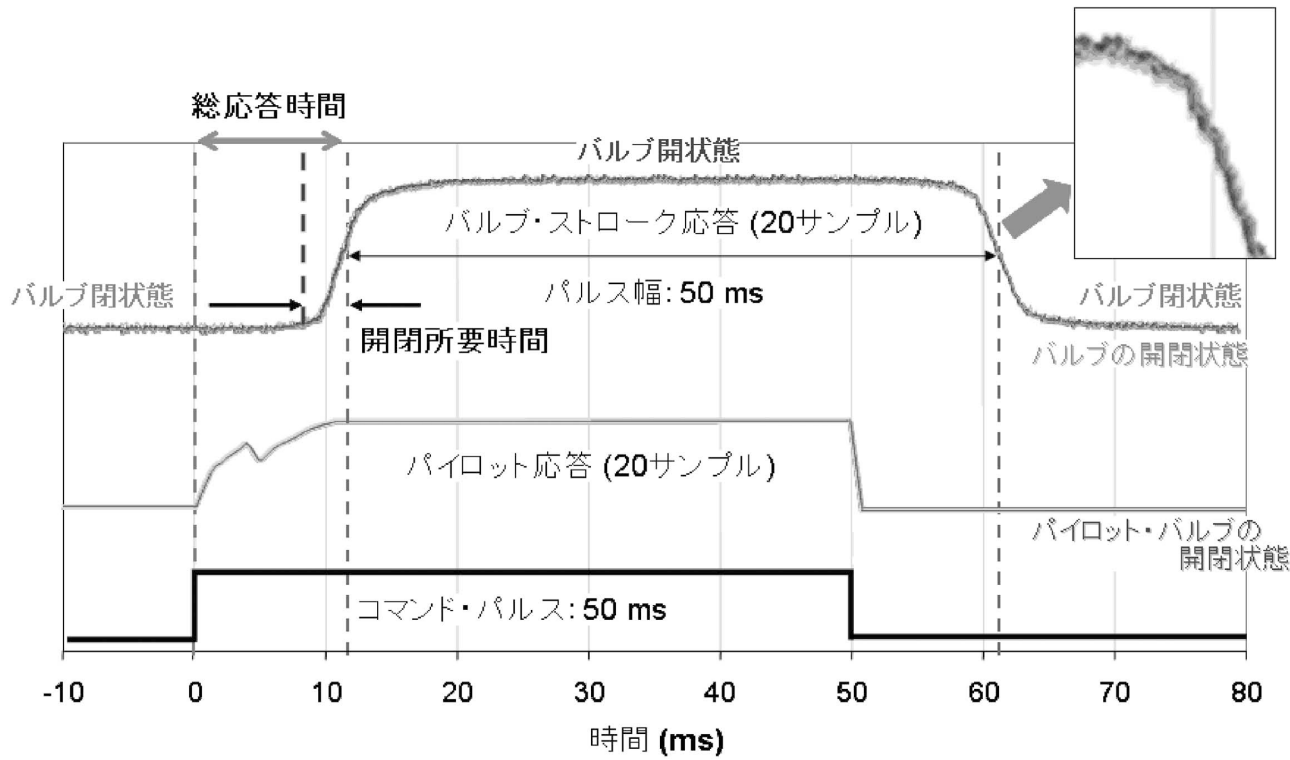

図 4 高速作動の応答性およびその再現性

が明らかになった（図 3 参照).

\section{3 高速のバルブ開閉動作}

空気作動式 ALD プロセス用バルブに対して, 以下の高速 パルス信号に対する応答性抢よびその高速作動の再現性の検 証テストを行った。

バルブの開閉を指示する $5 \mathrm{~V}$ のコマンド信号を受け（こ のコマンド信号の ON から OFF までが 1 回のコマンドパル ス)，パイロット・バルブ（電磁弁）がバルブを開き始めて 作動させるための空気を ALD プロセス用バルブに供給を開 始する．この空気を受けた ALD プロセス用バルブが全閉状 態から全開の $80 \%$ 状態まで（或いは全開状態から全開の 80 \%状態まで）ストロークするために必要な時間を「開閉所要 時間」と定義し，ストロークは線形可変差動変換器を用いて 直接ダイヤフラムの動作を測定した。 またコマンド信号，パ イロット・バルブ信号抢よびストロークはオシロスコープで 連続測定した. 図 4 はランダムに選び出した 1 台のバルブ に対して 2 時間にわたり 1 秒当たり 5 サイクルでバルブ開 閉を行ったデーターから20個のパルスを個別且つ無作為に 抽出し，それらを重祮合わせて表示した結果を示す。開閉所
要時間は㧍よそ $5 \mathrm{~ms}$ であり,この「開閉所要時間」に「コ マンド信号が発せられてからバルブが開き始めるまでに掛か った時間」を加えた「総応答時間」（つまりコマンド信号が 発せられてからバルブが全開状態になるまでの所要時間）が 抢よそ15 msであることが確認できた。

勿論, この総応答時間にはパイロット・バルブと ALD プ ロセス用バルブの接続に用いるプラスチック・チューブの長 さ, 肉厚, 種類そして供給ガスの圧力が影響を与える.これ らに対しても評価を行っている11が，本稿では誌面に限りが あるため割愛する。

\section{4 長寿命}

バルブの開閉寿命とは, バルブ • シート材の特性や金属に ストレスを与えるバルブのストローク，使用条件等が複合し た結果であり, バルブの閉状態が確保できなくなるまでの開 閉回数である.

従来のプロセスに於けるガスの供給サイクルは，せいぜい 数十秒に 1 回であった. つまり一般的なダイヤフラム・バ ルブで「保証值」もしくは「平均故障寿命（MTTF）」とし て示されている100〜200万回の開閉寿命であれば，バルブ 


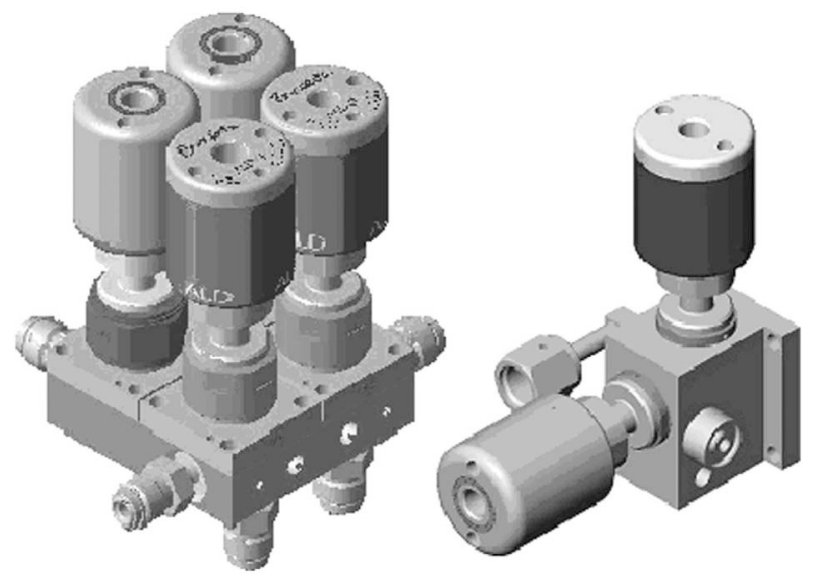

図 5 スウェージロック社製「ALD シリーズ」バルブ（特別 仕様品)

自体は装置の想定寿命よりも遥かに長寿命ということにな り，大きな問題となることはなかった.

一方, ALD プロセスでは, 膜形成プロセスがガス導入と パージの「高速スイッチング」によって行われ，その 1 プ ロセスにかかるサイクル時間は 0.5 秒にも満たない。つま り，従来のバルブであれば，二カ月半〜五ヶ月程度で「寿命」 が尽きてしまう。

数百パターンにも及ぶコンピューターを用いたバーチャル な応力解析/デザイン変更を繰り返して我々が見出した結論 は，『ダイヤフラムをバルブ・シートに押し付けシールを形 成する際のごく僅かなブレが，理想的なストレスを妨げてい た』ということであった．更にこの「ブレ」とは，ダイヤフ ラムのドーム形状のバラつきやピストンの寸法/アライメン トのバラつき，ダイヤフラムとピストン間のボタンの強度/ 寸法のバラつきだけでなく，ピストンのＯリングとピスト ン・シリンダーの内面で生じる僅かな摩擦差によっても生じ ることが確認できた，これらの結果を踏まえ，各部品の公差 管理をより厳密にすると同時にピストン・シリンダーの内面
を弊社で施せる最高の機械加工時技術にて均一に切削, 研磨 することで，バルブの開閉寿命を 4,000 万回超まで向上させ ることに成功した.

\section{ALD プロセス用「ALD シリーズ」バルブ}

以上のような経過を経てスウェージロック社では, 上記で 述べてきた性能も含め, SEMI 規格に示されたクリーン度, リークタイト性能等を完全にクリアした性能を持った 「ALD シリーズ」バルブを販売するに至っている．ラインア ップも継手ェンドからサーフェスマウントと様々な接続形態 に対応しており, 現在ではより個別のお客様のシステムに特 化し, 例えばチャンバーへ直に取り付けられるよう複数のバ ルブをブロック化してご提供することも行っている（図 5 参 照).

\section{6. おわりに}

我々は「高温仕様」,「安定して再現性のある流量」,「高速 のバルブ動作」,「長寿命」という 4 つの開発課題を設け, それらをかなりのレベルで解決してこられたものと考えてい る. 我々はそれらを一つ一つ解決して次に進むと言う形式を とったわけではなく，「一つを解決すると一つが影響を受け る」或いは「一つを解決すると二つ同時に解決できる」とい ったステップを忍耐強く継続し，バランスを常に意識しなが らバルブが最高の性能を発揮できるよう個々の課題を解決し てきたことが扮分かり頂ければ, 筆者としてはまことに幸甚 である。

我々スウェージロック・グループとして「更なる課題」を 読者諸氏と共に見出し, 次世代 ALD プロセスの構築に寄与 できる機会のあることを切に願いつつ，本稿を終えることと したい.

\section{〔文献〕}

1) http://www.swagelok.co.jp/downloads/webcatalogs/jp/ms-06106.PDF 